\title{
Evaluation of effects of electronarcosis stunning on broiler chickens' welfare and meat quality
}

\author{
Guilherme Maroldi Kidal, Guilherme Baú Torezan², Ana Maria Bridi', Alexandre Oba², \\ Ana Paula Ayub da Costa Barbon ${ }^{1}$, Caio Abércio da Silval, Rafael Humberto de Carvalho ${ }^{1,2 *}$
}

A b s tr a c t: This study aimed to evaluate the electrical parameters during stunning by electronarcosis and their influence on broiler chicken welfare and meat quality. The research was carried out on 500 broilers, divided into 5 treatments with 100 broilers each. After unloading for slaughter, the birds' haematomas and fractures were evaluated. Subsequent to the groups' evaluation and separation, the electrical parameters were adjusted and the broilers were hung and electrically stunned in a water bath at a commercial slaughterhouse. The five different electrical parameters were: $T 0=$ No electrical stunning (Halal); $T 1=95 \mathrm{~V}, 600 \mathrm{~Hz}$ and $2.4 \mathrm{~A}$; $T 2=125 \mathrm{~V}, 1200 \mathrm{~Hz}$ and $2.88 \mathrm{~A} ; \mathrm{T3}=129 \mathrm{~V}, 1500 \mathrm{~Hz}$ and $2.88 \mathrm{~A}$ and $\mathrm{T} 4=216 \mathrm{~V}, 1500 \mathrm{~Hz}$ and $2.88 \mathrm{~A}$. Following the slaughter line, the birds were submitted to bleeding, scalding and feather removal. Carcasses were removed from the line and evaluated individually, recording both the carcass sites where haematomas and fractures were found and $\mathrm{pH}$ values $\left(\mathrm{pH}_{15 \mathrm{~min}}\right)$. Carcasses followed the industrial process, and at the end, the breast fillets were removed and stored $\left(4^{\circ} \mathrm{C}\right)$ for $24 \mathrm{~h}$ for $\mathrm{pH}$, colouration $\left(L^{*}, a^{*}\right.$ and $\left.b^{*}\right)$ and water holding capacity analysis. The different electrical parameters used in stunning through the electronarcosis method had a direct influence on the haematoma and fracture levels, since T0 (63.8\%) and T2 (61.7\%) had high levels of haematomas and T0 (5.8\%) a high level of fractures. The parameters of $\mathrm{pH}$, colouration and water holding capacity showed differences between the various treatments used. The method of slaughter without electrical stunning presented the worst rates of these parameters among the evaluated electrical stunning methods.

Keywords: fracture, Halal, haematoma, poultry, slaughterhouse.

\section{Introduction}

World population growth is associated with increased demand for food, especially animal proteins that are widely produced and consumed around the world. Due to the high number of poultry animals slauFghtered for human consumption, requirements such as birds' welfare during the slaughter process and product quality have become a matter of concern to consumers (USDA, 2018).

According to the World Society for the Protection of Animals (WSPA, 2010), factors such as product quality, biosecurity and sustainability are important questions for the continued production of broiler chickens, but not less important is the humanitarian slaughter that has been increasingly gaining the consumers' attention. In accordance with the World Organization for Animal Health (OIE, 2004), the humanitarian slaughtering procedure is the set of scientific and technical guidelines that ensure poultry welfare, from birds' reception in the slaughter premises until the bleeding operation. In the context of humanitarian slaughter, the best-known chicken stunning method used by commercial slaughterhouses is electrical stunning (electronarcosis) (Sirri et al., 2017). Stunning is a process responsible for leading the animal to a state of immediate loss of consciousness caused by the inhibition of impulses in reticular activating and somatosensory systems (Heath et al., 1994). In this process, enough electric current to induce convulsion and insensitivity to pain must reach the bird's encephalon, while maintaining the vital functions until the bleeding stage (Gregory and Wotton, 1989). The insensitivity period enables the animal to be slaughtered without suffering pain or affliction, thus reducing the bird's response to stress at the time of slaughter. In addition, it promotes the birds' immobilisation and facilitates cutting of the main neck vessels (OIE, 2004).

The electrical stunning methods can lead to pain and suffering, higher incidence of fractures, haemorrhagic spots and meat defects, such as the appearance of pale, soft and exudative meat (PSE), resulting in

\footnotetext{
${ }^{1}$ Philadelphia University Center, Department of Veterinary Medicine, Londrina, Paraná, Brazil;

${ }^{2}$ Londrina State University, Agricultural Sciences Center, Graduate Program in Animal Science, Department of Animal Science, Londrina, Paraná, Brazil.
}

*Corresponding author: Rafael Carvalho, rafael.carvalho@uel.br 
significant losses to the poultry industry (WSPA, 2010; Savenije et al., 2002). All broilers must be stunned before slaughter, except in cases of religious precepts, which are required by a particular religious community or when meat is destined for commercial regions that require this exigency (Girasole et al., 2015).

In this regard, according to the Gulf Standardization Organization (GSO, 2015), which establishes the requirements for animal slaughter according to Islamic rules (Halal), electric shock and any other forms of shock should not be used in the process of slaughtering birds. Halal slaughter, which follows the most traditional Islamic precepts, such as Saudi Arabia's, has been questioned by animal rights activists who claim that sacrifice without stunning can cause pain and suffering (Shahdan et al., 2016). Nevertheless, to export to more tolerant countries, Halal slaughter allows electronarcosis, as long as the stunning process does not cause cardiac arrest induction of the bird (Fuseini et al., 2018). Therefore, due to its importance in animal welfare, religious precepts and product quality, the objective of this study was to evaluate and compare the effects of non-stunning and stunning with different electrical parameters in broilers, and the influence of the stunning methods on bruises, fractures and final meat quality, following the precepts of animal welfare.

\section{Material and Methods}

All procedures adopted in this research were previously approved by the Animal Use Ethics Committee of the Philadelphia University Center, (CEUA 000/2019).

\section{Pre-slaughtering broilers}

The 48-day-old Cobb $^{\circledR}$ broiler chickens $(n=500)$ of both sexes were conventionally prepared for slaughter with a 10-hour fast before hanging. The broilers were manually caught, respecting the capacity of $22 \mathrm{~kg}$ per cage, and transported in trucks. In the slaughterhouse, on the resting platform, the broilers were bathed with sprinkling water at ambient temperature immediately before slaughter. The ambient temperature and the relative humidity varied from 20.8 to $28.6^{\circ} \mathrm{C}$ and 55 to $78 \%$, respectively, during the experiment. Before slaughter, a total of 125 broilers were separated and divided into 25 broilers per treatment for each day $(n=4)$ analysed.

\section{Experimental procedure and sample collection}

The broilers were evaluated after unloading the cages in the slaughterhouse to register the presence of bruises and fractures and the respective affected sites. The evaluation sites for recording bruises were wing tip, mid wing, wing drumstick, breast and thigh, divided into left and right sides (Figure 1A). The sites evaluated for recording fractures were wing tip, mid wing, wing drumstick and thigh, divided into left and right sides (Figure 1B). Both bruises and fractures were counted as a total value per animal. This procedure was performed to identify the animals that had bruises and fractures derived from before the slaughter process.

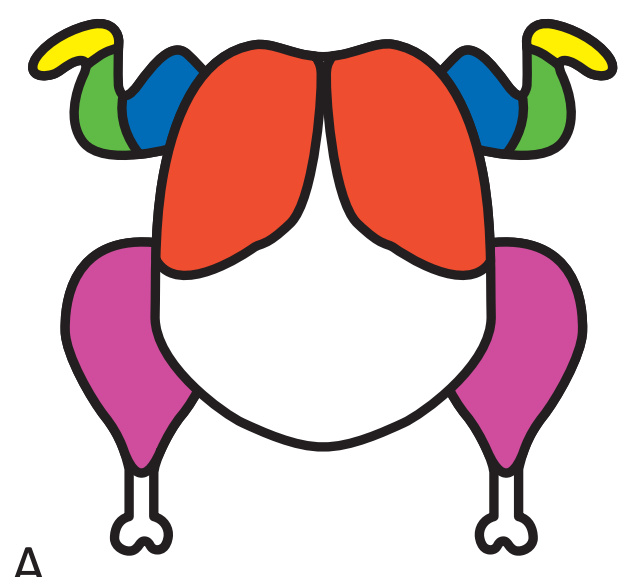

A

Figure 1. (A) Bruising evaluation sites: wing tip (yellow), mid wing (green), wing drumstick (blue), breast (red) and thigh (purple). (B) Fracture evaluation sites: wing tip (yellow), mid wing (green), wing drumstick (blue) and thigh (purple). 
Table 1. Electrical desensitisation parameters: voltage, frequency and amperage for different treatments.

\begin{tabular}{lccccc}
\hline Treatments & T0* & T1 & T2 & T3 & T4 \\
\hline Voltage (V) & - & $95 \mathrm{~V}$ & $125 \mathrm{~V}$ & $129 \mathrm{~V}$ & $216 \mathrm{~V}$ \\
Frequency (Hz) & - & $600 \mathrm{~Hz}$ & $1200 \mathrm{~Hz}$ & $1500 \mathrm{~Hz}$ & $1500 \mathrm{~Hz}$ \\
Amperage (A/24 broilers) & - & $2.4 \mathrm{~A}$ & $2.88 \mathrm{~A}$ & $2.88 \mathrm{~A}$ & $2.88 \mathrm{~A}$ \\
\hline
\end{tabular}

Legend: * Broilers that did not go through the electric stunning process, religious precept (Shahdan et al., 2016).

At the end of the individual evaluation of each broiler, they received an identification seal on their thigh. After the electrical parameter was properly adjusted in the equipment, the group of broilers $(n=125)$, previously inspected, identified and separated, was hung on the slaughter line in order to immerse the broilers in the electric stunner machine.

Previous to slaughter, the broilers were divided into five treatments (Table 1), based on the application of the electrical stunning in an immersion bath or without electrical stunning. One hundred broilers were used per treatment, and they were divided into four replications on different days.

Electrical sensitisation was performed in a stunning Fluxo 3.0 ${ }^{\circledR}$, with variable electric current, submerging the broilers' heads in salted potable water. The electrical parameters used contained different variations of voltage $(\mathrm{V})$, amperage $(\mathrm{A})$ and frequency $(\mathrm{Hz})$, but the type of electric current, square alternating with duty cycle $50 \%$, and the broilers' exposure period in the electric stunning machine were kept the same for all groups. The broilers were stunned for ten seconds, and the stunning settings were based on the terrestrial animal health code (OIE, 2004). The humanitarian bird slaughter manual (WSPA, 2010) was used with adaptations.

After stunning, the broilers were evaluated for the efficiency parameters in the electronarcosis process and for welfare parameters, assuring that the examined methods would not cause death or injuries to the animals. All broilers were assessed immediately after leaving the desensitisation bowl, using visual analysis and a digital chronometer to evaluate the absence of rhythmic cloacal breathing, presence of body tremors, absence of coordinated wing beat, arched neck, lack of vocalisation, wings close to the body with tremors and absence of eyelid reflex, which indicate an efficient stunning process that does not hurt the animals, inducing neither pain nor discomfort at the time of slaughter.

Manual bleeding was performed within $10 \mathrm{sec}-$ onds after stunning. The bleeding period was approximately 3.5 minutes for all treatments.
After slaughter, following standard industrial practices, carcasses were scalded at $52^{\circ} \mathrm{C}$ for two minutes and the feathers were removed automatically by machine. At this point, the carcasses were removed from the slaughter line and the same sites for bruises and fractures (Figure 1) were re-examined. The carcasses' $\mathrm{pH}$ value (15 min) was also measured, then they were returned to the line they followed for automatic evisceration, pre-chiller (4 to $16^{\circ} \mathrm{C} / 28$ min) and chiller (0 to $\left.4^{\circ} \mathrm{C} / 54 \mathrm{~min}\right)$. Breast fillets (Pectoralis major) were collected approximately $1 \mathrm{~h}$ and 40 minutes postmortem and stored at $4^{\circ} \mathrm{C}$ for $24 \mathrm{~h}$ for $\mathrm{pH}$, colour ( $\mathrm{L}^{*}, \mathrm{a}^{*}$ and $\left.\mathrm{b}^{*}\right)$ and drip loss analysis.

\section{Colour and pH measurement}

The $\mathrm{pH}$ values (15 min and $24 \mathrm{~h})$ were determined by introducing the electrode directly into the breast muscle with the contact potentiometer (Testo, Model 205). The analyses were performed in $24 \mathrm{~h}$ postmortem triplicates as described by Carvalho et al. (2017).

The Colorimeter (Minolta CR 400) was used to evaluate the colour parameters of L* (luminosity), $\mathrm{a}^{*}$ (red component) and $\mathrm{b}^{*}$ (yellow component) on the fillet's ventral surface, taking five different recognition points per sample, according to the methodology described by Carvalho et al. (2017).

\section{Water holding capacity (WHC)}

The analysis was performed as described by Honikel (1998). To determine weight loss during storage, approximately $2 \mathrm{~g}$ amounts of breast fillet were weighed before and after storage $\left(4^{\circ} \mathrm{C}\right)$. The WHC was expressed as a percentage derived from the ratio differences between the samples' initial and final weights, as shown below:

$$
W H C(\%)=\frac{P f(g) \times 100}{P i(g)}
$$

where Pf is final weight and Pi is initial weight. 


\section{Chicken fillet classification}

Chicken fillets were classified as either PSE or normal meats, based on $\mathrm{pH}$ and $\mathrm{L}^{*}$ values as described by Carvalho et al. (2017). Therefore, the fillets with $\mathrm{L}^{*} 24 \mathrm{~h} \geq 53.0$ and $\mathrm{pH} 15 \mathrm{~min} \leq 5.80$ values were classified as PSE, while fillets under $44.0<\mathrm{L} * 24 \mathrm{~h}<53.0$ and $5.80<\mathrm{pH} 15 \mathrm{~min}<6.00$ values were considered normal. For incidences of PSE meat, the binary variation (1 and 0$)$ was used, with 1 indicating PSE meat and 0 normal meat.

\section{Statistical analysis}

The Statistica software for Windows 13.0 (StatSoft, Tulsa, USA) was used. Tukey's test at $1 \%$ probability $(\mathrm{p}<0.01)$ was used for comparing the differences among the five treatments.

\section{Results and discussion}

Individual analysis of 500 broilers before and after slaughter allowed the number of bruises and fractures already obtained in the pre-hanging stages to be discarded, and isolation of the injuries caused at the slaughterhouse. Thus, the influence of each stunning method used was quantified. The bruise and fracture rates for each type of treatment applied is shown in Table 2.

The results show the broilers which were not submitted to electrical stunning (T0) and the T2 group presented with higher incidences of bruising $(p<0.01)$ when compared to the other treatments. The T4 group presented a lower bruising incidence, and thus, better results than treatments $\mathrm{T} 0$ and $\mathrm{T} 2$, which corresponded to differences of $32.4 \%$ and $30.3 \%$, respectively.

The non-stunning method caused a higher incidence of fractures than did the other treatments $(\mathrm{p}<0.01)$, since T0 presented with $5.7 \%, 4.8 \%, 5.4 \%$ and $5.3 \%$ higher fracture incidence than $\mathrm{T} 1, \mathrm{~T} 2, \mathrm{~T} 3$ and $\mathrm{T} 4$ treatments, respectively.
The differences between T0 without stunning, which presented higher haematoma and fracture rates, and the other groups analysed are due to the broilers' agitation during the bleeding process. Wilkins (1998) and Cuadrado (2012) indicate the negative effects caused by stunning can be reduced through higher frequencies, since the muscle contraction strength caused by the broiler's electrical stimulation is reduced, resulting in fewer bone fractures and muscle bruises. This effect was verified in our study by comparing the T2 and T3 treatments, in which the percentage of haematoma was significantly higher when the frequency was $1500 \mathrm{~Hz}$ (T3) than when the frequency was $1200 \mathrm{~Hz}$ (T2).

The combination of high voltage and high frequency, as performed in T4, produced lower haematoma rates due to the better stunning process, since the use of high voltage promotes greater efficiency of stun, as it rejects the resistance value according to Ohm's law represented by the formula V=R.I; where $\mathrm{V}$ is the voltage measured in volt $(\mathrm{V}), \mathrm{R}$ is the electrical resistance measured in $\mathrm{Ohm}(\Omega)$, and $\mathrm{I}$ is the intensity of electric current measured in ampere (A) (Parks, 2007).

According to Scheuermann (2017), broilers' electric desensitisation with approximate electric current of $100 \mathrm{~mA}$ per broiler, frequency of $600 \mathrm{~Hz}$ and voltage at $96 \mathrm{~V}$, enables the passage of electric current in the broiler's brain in greater magnitude than is normally used for neurological activity, so constitutes the minimum electrical premises for an effective stunning process. This parameter, utilised in $\mathrm{T} 1$, resulted in low haematoma and fracture rates, due to this low electric tension producing relatively little muscle contraction.

The $\mathrm{pH}$ values at 15 minutes and after 24 hours, the colouration $\left(\mathrm{L}^{*}\right),\left(\mathrm{a}^{*}\right)$ and $\left(\mathrm{b}^{*}\right)$ and WHC (Table 3) show the poultry submitted to slaughter without stunning presented a lower $\mathrm{pH} 15 \mathrm{~min}$ value $(\mathrm{p}<0.01)$ than did the other treatments.

Anaerobic glycolysis occurs over time after slaughter and results in lactate formation and accumulation in the muscle, which reduces meat $\mathrm{pH}$, as

Table 2. Incidences of bruise (\%) and fracture (\%) in broilers according to stunning method.

\begin{tabular}{lccccc}
\hline Treatments & T0 & T1 & T2 & T3 & T4 \\
\hline Bruises (\%) & $63.80^{\mathrm{a}} \pm 12.66$ & $41.80^{\mathrm{c}} \pm 12.57$ & $61.70^{\mathrm{a}} \pm 8.19$ & $51.20^{\mathrm{b}} \pm 11.15$ & $31.40^{\mathrm{d}} \pm 7.05$ \\
Fractures (\%) & $5.80^{\mathrm{a}} \pm 1.75$ & $0.01^{\mathrm{b}} \pm 0.03$ & $1.00^{\mathrm{b}} \pm 2.21$ & $0.40^{\mathrm{b}} \pm 0.51$ & $0.50^{\mathrm{b}} \pm 0.05$ \\
\hline
\end{tabular}

Legend: Different superscript letters in the same row represent statistically different averages by Tukey's analysis with $1 \%$ significance. T0 = No electrical stunning (Halal); T1 $=95 \mathrm{~V}, 600 \mathrm{~Hz}$ and $2.4 \mathrm{~A}$; T2 $=125 \mathrm{~V}, 1200 \mathrm{~Hz}$ and $2.88 \mathrm{~A}$; T3 $=129 \mathrm{~V}, 1500 \mathrm{~Hz}, 2.88 \mathrm{~A}$ and $\mathrm{T} 4=216 \mathrm{~V}, 1500 \mathrm{~Hz}$ and $2.88 \mathrm{~A}$. 
Table 3. $\mathrm{pH}(15 \mathrm{~min}$ and $24 \mathrm{~h})$, colouration ( $\mathrm{L} * \mathrm{a} *$ and $\mathrm{b} *$ ) and water holding capacity (WHC) values for different sensitisation parameters.

\begin{tabular}{lccccc}
\hline & T0 & T1 & T2 & T3 & T4 \\
\hline pH15min & $5.99^{\mathrm{d}} \pm 0.12$ & $6.39^{\mathrm{a}} \pm 0.17$ & $6.27^{\mathrm{ab}} \pm 0.12$ & $6.21^{\mathrm{bc}} \pm 0.18$ & $6.31^{\mathrm{ab}} \pm 0.12$ \\
$\mathrm{pH} 24 \mathrm{~h}$ & $5.76^{\mathrm{a}} \pm 0.12$ & $5.83^{\mathrm{a}} \pm 0.17$ & $5.78^{\mathrm{a}} \pm 0.12$ & $5.86^{\mathrm{a}} \pm 0.18$ & $5.81^{\mathrm{a}} \pm 0.12$ \\
$\mathrm{~L}^{*}$ & $53.29^{\mathrm{a}} \pm 1.71$ & $49.90^{\mathrm{b}} \pm 1.69$ & $50.39^{\mathrm{b}} \pm 1.89$ & $50.71^{\mathrm{b}} \pm 1.72$ & $49.18^{\mathrm{b}} \pm 2.01$ \\
$\mathrm{a}^{*}$ & $2.64^{\mathrm{a}} \pm 0.92$ & $1.42^{\mathrm{b}} \pm 0.99$ & $1.79^{\mathrm{ab}} \pm 0.85$ & $1.14^{\mathrm{b}} \pm 0.58$ & $1.53^{\mathrm{b}} \pm 0.87$ \\
$\mathrm{~b}^{*}$ & $5.24^{\mathrm{a}} \pm 1.66$ & $6.12^{\mathrm{a}} \pm 1.94$ & $6.31^{\mathrm{a}} \pm 0.88$ & $6.20^{\mathrm{a}} \pm 2.08$ & $5.70^{\mathrm{a}} \pm 1.55$ \\
WHC $(\%)$ & $93.32^{\mathrm{b}} \pm 1.11$ & $95.52^{\mathrm{a}} \pm 1.30$ & $94.60^{\mathrm{ab}} \pm 1.0$ & $95.25^{\mathrm{a}} \pm 1.35$ & $95.86^{\mathrm{a}} \pm 1.18$ \\
\hline
\end{tabular}

Legend: Different superscript letters in the same row represent statistically different average results by Tukey's test with $1 \%$ significance $(\mathrm{p}<0.01)$. T0 = No electrical stunning (Halal); T1 $=95 \mathrm{~V}, 600 \mathrm{~Hz}$ and $2.4 \mathrm{~A} ; \mathrm{T} 2=125 \mathrm{~V}, 1200 \mathrm{~Hz}$ and $2.88 \mathrm{~A} ; \mathrm{T} 3=129 \mathrm{~V}, 1500$ $\mathrm{Hz}$ and $2.88 \mathrm{~A}$ and $\mathrm{T} 4=216 \mathrm{~V}, 1500 \mathrm{~Hz}$ and $2.88 \mathrm{~A}$.

shown by the lower $\mathrm{pH}$ at $24 \mathrm{~h}$ after slaughter than $\mathrm{pH}$ at 15 mins post-slaughter in all treatments (Lawrie 2005).

The stress caused at the time of slaughter can be noticed by the accentuated $\mathrm{pH}$ decrease in the first 15 minutes in non-stunned poultry (T0). Acute stress in birds causes release of catecholamines and glucocorticoids that accelerate the animal's metabolism, so anaerobic glycolysis occurs at a much higher rate in non-stunned than in stunned broilers. When the carcass temperature is close to physiological $\left(40^{\circ} \mathrm{C}\right)$, low $\mathrm{pH}$ values occur due to myofibrillar and sarcoplasmic protein denaturation, as evidenced by the $\mathrm{pH}$ after 15 mins in the T0 group (Olivo et al., 2001; Ali et al., 2008; Carvalho et al., 2017).

According to Carvalho et al., (2017), pH is closely related to colouration and WHC.

The T0 group without stunning presented higher $L^{*}$ values $(p<0.01)$ than the other treatments. The $\mathrm{a}^{*}$ value for the group without stunning was higher $(p<0.01)$ than those of treatments T2 and T3, being 0.85 and 1.5 units greater, respectively. $\mathrm{B}^{*}$ values did not differ between the analysed groups $(\mathrm{p}>0.01)$.

The $L^{*}$ value relates to luminosity, varying from white (100) to black (0). These values were higher $(\mathrm{p}<0.01)$ in the treatment without stunning compared to the others, indicating paler meat. Protein denaturation derived from the acute stress process, as found in $\mathrm{T} 0$, promotes pale meat, due to higher birefringence with less light transmitted by the fibres. Thus, a greater amount of light is scattered and the meat appears lighter in colour (Bendall and Swatland, 1988; Swatland, 1995).

The data related to the treatment without stunning denote the stress the poultry went through, being identified by the low $\mathrm{pH}$ value observed in the first minutes after slaughter, the high $\mathrm{L}^{*}$ rate in the luminosity evaluation and the low WHC.

$\mathrm{a}^{*}$ values, related to green to red shades, indicated higher red shades for $\mathrm{T} 0$ and $\mathrm{T} 2$, due to the greater agitation of broilers during slaughter and occasionally higher bruising and splattering rates. According to Kranen et al. (2000), with pectoralis muscle haemorrhages, histological studies show their morphological appearance and blood leakage is determined by the structure of the tissue and the amount of blood leaving the circulation. The diversity of type and bleeding location indicates that bleeding is caused by several different mechanisms including electronarcosis.

According to Fernandes (2004), WHC is defined as meat's ability to retain its moisture or water during the application of external forces. The highest WHC values were seen in the T4 group $(\mathrm{p}<0.01)$, with broilers submitted to high frequency and high voltage desensitisation, being 2.54 percentage points and 1.26 percentage points higher than groups $\mathrm{T} 0$ and $\mathrm{T} 2$, respectively.

The WHC of meat is a very important quality attribute that influences the productivity of meat product, which in turn has economic implications, but is also important in terms of product quality and sensory quality. WHC is directly involved with meat cooking and cooling procedures, more specifically the heating and cooling rates that can influence the palatability and succulence of the final product (Cheng, 2008).

Increased lactic acid production with consequent $\mathrm{pH}$ decrease (Table 3), associated with high body temperature immediately after slaughter, cause denaturation and loss of muscle protein solubility, leading to decreased WHC (Mckee and Sams, 1998; Van Laak et al., 2000; Carvalho et al., 2017), a fact indicated in the $\mathrm{T} 0$ group when compared to the other treatments. 


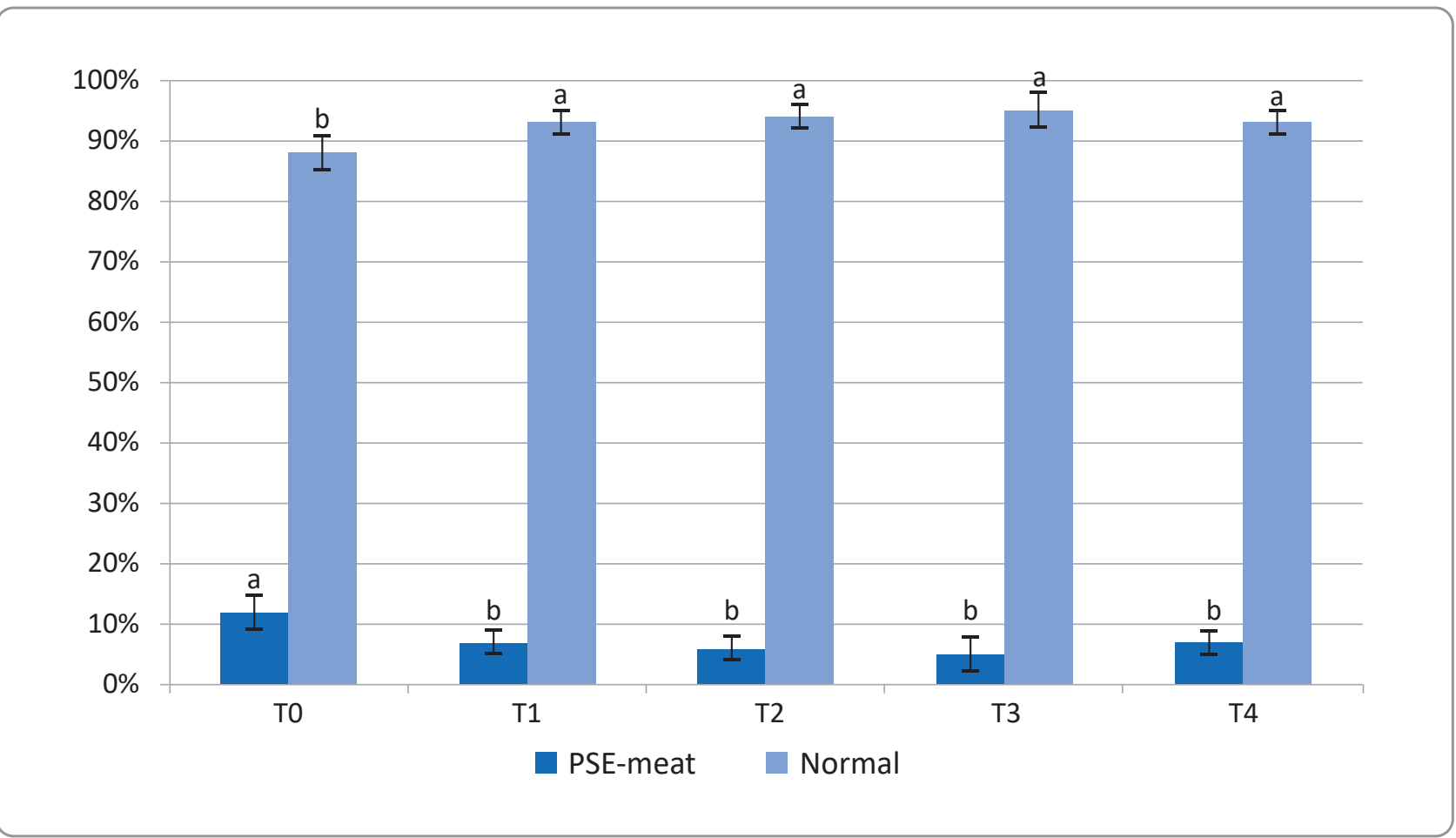

Figure 2. Percentages of PSE and normal meat for five different stunning procedures.

Legend: $\mathrm{T} 0=$ No electrical stunning (Halal); $\mathrm{T} 1=95 \mathrm{~V}, 600 \mathrm{~Hz}$ and $2.4 \mathrm{~A}$; T2 = $125 \mathrm{~V}, 1200 \mathrm{~Hz}$ and $2.88 \mathrm{~A} ; \mathrm{T} 3=129 \mathrm{~V}, 1500 \mathrm{~Hz}$ and $2.88 \mathrm{~A}$ and T4 $=216 \mathrm{~V}, 1500 \mathrm{~Hz}$ and $2.88 \mathrm{~A}$. Standard deviation bars are indicated at the top of the bars. Significant differences presented by Tukey's test at $1 \%(\mathrm{p}<0.01)$ are demonstrated at the tops of the bars for each stunning procedure. $n s=$ not significant. $\mathrm{n}=25$ per treatment.
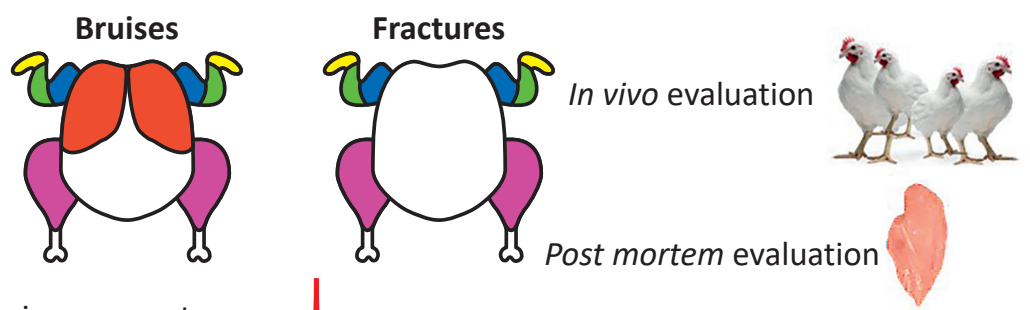

Electronarcosis stunning parameters

$\begin{array}{cc}\text { Without stunning* } & \text { 95V, 600Hz, 2.4A } \\ \text { Bruises 63.8\% } & \text { Bruises 41.8\% } \\ \text { Fractures 5.8\% } & \text { Fractures 0.01\% } \\ \text { pH 15 min 5.99 } & \text { pH 15 min 6.39 } \\ \text { WHC 93.32\% } & \text { WHC 95.52\% } \\ \text { L* value 53.29 } & \mathrm{L}^{*} \text { value } 49.90 \\ \text { a* value 2.64 } & \text { a* value } 1.42\end{array}$

$125 \mathrm{~V}, 1200 \mathrm{~Hz}, 2.88 \mathrm{~A}$
Bruises $61.7 \%$
Fractures $1.0 \%$
$\mathrm{pH} 15$ min 6.27
WHC $94.60 \%$
$\mathrm{~L}^{*}$ value 50.39
$\mathrm{a}^{*}$ value 1.79

129V, $1500 \mathrm{~Hz}, 2.88 \mathrm{~A}$
Bruises $51.2 \%$
Fractures $0.4 \%$
pH $15 \min 6.21$
WHC $95.25 \%$
L* value 50.71
a* value 1.14

$216 \mathrm{~V}, 1500 \mathrm{~Hz}, 2.88 \mathrm{~A}$

* Halal method; $\mathrm{V}=$ Volts; $\mathrm{H}=$ Hertz; $\mathrm{A}=$ Ampere

Figure 3. Proposed mechanisms for the observed effects of electronarcosis stunning on meat quality of chicken thigh meat.

Legend: WHC $=$ Water holding capacity 
The incidence of PSE meat did not significantly differ between the desensitised groups ( $p>0.01)$, but differed significantly from that of the $\mathrm{T} 0$ group without stunning $(\mathrm{p}<0.01)$. The non-stunning of broilers (T0) resulted in $88 \%$ of meat presenting normal characteristics and $12 \%$ presenting PSE characteristics, due to the acute stress caused at the time of slaughter without any electrical stunning. This immediately increased the birds' metabolism, seen by rapid muscle glycogen depletion and meat $\mathrm{pH}$ reduction caused by lactic acid accumulation, while carcass temperatures were still in physiological patterns (Carvalho et al., 2017). This biotransformation denatures myofibrillar and sarcoplasmic proteins that are directly involved with meat tenderness and pale colouration in the final product.

The other treatments presented rates of $93 \%$ of normal meat and 7\% PSE in T1 treatment; 94\% normal meat and $6 \%$ PSE in T2; $95 \%$ normal meat and $5 \%$ PSE in T3 and 93\% normal meat and 7\% PSE in $\mathrm{T} 4(\mathrm{p}>0.01)$.

The results show the stunning stage should be submitted to greater control during poultry processing, since it interferes with the final product quality and the utilisation of the cuts obtained. The reduction of haematoma is importantly influenced by stunning, as there was 30.3 percentage points less bruising in the desensitised groups (T4 and T2), and 32.4 percentage points less bruising in the T4 group (with stunning) than in the T0 group (without stunning). The WHC of chicken fillets differed insignificantly $(p>0.01)$ between the desensitised groups, unlike the non-desensitised group (T0) that had a lower WHC, resulting in product with higher exudative characteristics and of lower quality.

All electrical configurations tested effectively stunned the broilers, keeping them in a state of unconsciousness until the moment of slaughter and not causing the death of the animals during the electronarcosis process. Figure 3 summarises the proposed mechanisms by which electronarcosis stunning can influence the birds' welfare and chicken meat quality.

\section{Conclusion}

Not using any stunning caused more bruising and fractures due to greater movement of broilers at the time of slaughter. Otherwise, stunning with high voltage and frequency $(216 \mathrm{~V}, 1500 \mathrm{~Hz}$ and $120 \mathrm{~mA}$ per broiler) caused significantly fewer bruises and fractures by causing better stunning with fewer unwanted effects. Clearly, the parameters used in electrical desensitisation have a direct influence on meat quality and animal welfare, but deeper research is needed on the parameters to stipulate an ideal configuration for both the animal and the industry.

\title{
Ocena uticaja omamljivanja elektronarkozom na dobrobit i kvalitet mesa pilića
}

\author{
Guilherme Maroldi Kida, Guilherme Baú Torezan, Ana Maria Bridi, Alexandre Oba, \\ Ana Paula Ayub da Costa Barbon, Caio Abércio da Silva, Rafael Humberto de Carvalho
}

A p s tr a kt: Cilj ovog istraživanja je bio da se procene električne parametri tokom omamljivanja elektronarkozom i njihov uticaj na dobrobit pilića brojlera i kvalitet mesa. Istraživanje je sprovedeno na 500 brojlera, podeljenih u 5 tretmana sa po 100 brojlera. Nakon istovara za klanje, urađena je procena ptica na prisustvo hematoma i preloma. Nakon procene i razdvajanja grupa, električni parametri su prilagođeni, a brojleri su okačeni i omamljeni pomoću struje u vodenom kupatilu u komercijalnoj klanici. Pet različitih električnih parametara je korišćeno u istraživanju: T0 = bez električnog omamljivanja (Halal); T1 =95V, $600 \mathrm{~Hz} i 2,4 \mathrm{~A} ; \mathrm{T2}=125 \mathrm{~V}$, $1200 \mathrm{~Hz}$ i 2,88A; T3 =129V, 1500Hz i 2,88A i T4 =216V, 1500Hz i 2,88A. Nakon linije klanja, ptice su podvrgnute iskrvarenju, oparivanju/šurenju i uklanjanju perja. Trupovi su skidani sa linije klanja i pojedinačno procenjivani, beležeći i mesta na trupu na kojima su pronađeni hematomi i prelomi, kao i vrednosti $\mathrm{pH}$ (pH15min). Trupovi su pratili industrijski proces, gde su na kraju fileti grudi pilića odvojeni i čuvani $\left(4^{\circ} \mathrm{C}\right)$ tokom 24 sata za analizu $\mathrm{pH}$, boje $\left(L^{*}, a^{*}\right.$ i $\left.b^{*}\right)$ i kapaciteta zadržavanja vode. Različiti električni parametri koji se koriste za omamljivanje metodom elektronarkoze imali su direktan uticaj na nivo hematoma i preloma, budući da su T0 (63,8\%) i T2 $(61,7 \%)$ pokazali visok nivo hematoma, a T0 (5,8\%) visok nivo preloma. Parametri $p H$, boje i sposobnosti zadržavanja vode pokazali su razlike između različitih tretmana. Metoda klanja bez električnog omamljivanja pokazala je najgore stope ovih parametara među ocenjenim metodama električnog omamljivanja.

Ključne reči: prelom, halal, hematom, živina, klanica.

Disclosure statement: No potential conflict of interest was reported by authors. 


\section{References}

Bendall, J. R., Swatland, H. J. (1988). A review of the relationships of $\mathrm{pH}$ with physical aspects of pork quality. Meat Science, 24, (2), 85-126.

Carvalho, R. H., Ida, E. I., Madruga, M. S., Martínez, S. L., Shimokomaki, M. \& Estévez, M. (2017). Underlying connections between the redox system imbalance, protein oxidation and impaired quality traits in pale, soft and exudative (PSE) poultry meat. Food Chemistry, 215,129-137.

Cheng, Q., \& Sun, D. W. (2008). Factors affecting the water holding capacity of red meat products: a review of recent research advances. Critical Reviews in Food Science and Nutrition, 48(2), 137-159.

Cuadrado, M. V. (2012). Estudio del aturdimiento efectivo de patos mediante electronarcosis en baño de agua. Repercusiones sobre la calidad del producto final. Trabajo Fin de Máster en Calidad, Desarrollo e Innovación de Alimentos. Campus de Palencia. Universidad de Valladolid. Palencia, Espanha, (https:/uvadoc.uva.es/handle/10324/1428).

Fernandes de sá, E. M. (2004). A influência da água nas propriedades da carne. Revista Nacional da Carne, São Paulo, n.325, p.51-54.

Fuseini, A., Teye, M., Wotton, S. B., Lines, J. A., \& Knowles, T. G. (2018). Electrical water bath stunning for Halal poultry meat production: animal welfare issues and compatibility with the Halal rules. CAB Reviews, 13(016), 17,

Girasole, M., Chirollo, C., Ceruso, M., Vollano, L., Chianese, A., \& Cortesi, M. L. (2015). Optimization of stunning electrical parameters to improve animal welfare in a poultry slaughterhouse. Italian journal of Food Safety, 4(3),(https:// www.ncbi.nlm.nih.gov/pmc/articles/PMC5076635/).

Global Conference on Animal Welfare: An OIE Initiative. (2004). Paris. Available in: (http://www.rr-africa.oie.int/ docspdf/en/2004/Animal_welfare_conference_1.pdf).

Gregory N. G. \& Wotton S. B. (1989). Effect of electrical stunning on somatosensory evoked potentials in chickens. British Veterinary Journal, 145, 159-164, (https://www.sciencedirect.com/science/article/abs/pii/0007193589900985).

GSO - Gulf Standardization Organization 2015). www.gso. org.sa

Heath G. E., Thaler A. M., \& James W. (1994). O. A survey of stunning methods currently used during slaughter of poultry in commercial poultry plants. Journal of Applied Poultry Research, 3, 297-302.

Honikel, K. O. (1998). Reference methods for the assessment of physical characteristics of meat. Meat science, 49(4), 447-457.

Kissel, C. (2013). Efeito da insensibilização elétrica no estresse e incidência de carnes PSE (pale, soft and exudative) em frangos. Programa de pós-graduação em Ciência de Alimentos. Universidade Estadual de Londrina. Centro de Ciências Agrárias, (http://www.bibliotecadigital.uel.br/ document/?code $=$ vtls000185879).

Noving-Bolnik, K., Kranen, R. W., Klont, R. E., Gerritsen, K. H. \& de Greef F. (2000). Fibre area and capillary sup$\mathrm{pl}$ in broiler breast muscale in relation to productivity and ascites. Meat Science, 56(4), 397-402.
Lawrie, R. A., Marcos, B., \& Asuncion, E. Q. (2005). Ciência da carne, (https://www.bdpa.cnptia.embrapa.br/consulta/ busca? $b=a d \& i d=888731$ \&bibliotec $a=$ vazio \&busca $=$ autoria:\%22LAWRIE, \%20R.\%22\&qFacets =autoria : $\% 22$ LAWRIE, \%20R.\%22\&sort=\&paginacao= $t \&$ paginaAtual $=1)$.

Mckee, S. R. \& Sams, A. R. (1998). Rigor mortis development at elevated temperatures induces pale exudative turkey meat characteristics. Poultry Science, 77, 169-174.

OIE - World Organization for Animal Health - www.oie.int/ update-on-avian-influeza, 2004.

Olivo, R., Scares, A. L., Ida, E. I., \& Shimokomaki, M. (2001). Dietary vitamin E inhibits poultry PSE and improves meat functional properties. Journal of Food Biochemistry, 25(4), 271-283.

Papinaho, P. A. \& Fletcher, D. L. (1995). Effect of stunning amperage on broiler breast muscle rigor development and meat quality. Poultry science, 74(9), 1527-1532.

Papinaho, P. A., Fletcher, D. L. \& Buhr, R. J. (1995). Effect of electrical stunning amperage and peri-mortem struggle on broiler breast rigor development and meat quality. Poultry science, 74(9), 1533-1539.

Parks, J. E. (2007). Ohms Law III Resistors in Series and Parallel. Department of Physics and Anatomy, University of Tennessee, (http://www.phys.utk.edu/labs/Ohms\%20 Law\%20Series\%20Parallel\%20Resistors.pdf).

Savenije B., Lambooij, E., Gerritzen M. A., Venema K.\& Korf, J. (2002). Efects of feed deprivation and transport on preslaughter blood metabolites, earlz postmortem muscle metabolites, and meat quality. Poultry Science, 8(5), 699-708.

Scheuermann, G., Costa, E., Caron, L., Coldebella, A., Alves, S., de La vega, L. T., \& Rosa, P. (2017). Parâmetros elétricos para a insensibilização de frangos: qual a corrente elétrica que atinge o cérebro?. In Embrapa Suínos e Aves-Artigo em anais de congresso (ALICE). In: Salão internacional de avicultura e suinocultura, 2017, São Paulo. Anais: trabalhos científicos: produção. São Paulo: ABPA, 2017. p. 258-261. SIAVS, (https://www.alice.cnptia.embrapa.br/handle/doc/1078650).

Shahdan A., Regenstein J. M., Shahabudin A. S. M. \& Rahman M. T. (2016). Poultry Science, 95(1), 1680-1692.

Sirri, F., Petracci, M., Zampiga, M., \& Meluzzi, A. (2017). Effect of EU electrical stunning conditions on breast meat quality of broiler chickens. Poultry science, $96 \mathrm{n}^{\circ} 8$, p.3000-3004, (https://www.sciencedirect.com/science/ article/pii/S0032579119315019).

STATISTICA (Data Analysis Software System) (2006). v.13.0., StatSoft, Inc., USA (www.statsoft.com).

Swatland, H. J. (1995). On-line evaluation of meat. CRC Press, (https://books.google.com.br/books?hl=pt-BR\&lr=\&id=k SxH93b6bNkC\&oi=fnd\&pg=PR11\&dq=Swatland, + H. + J. + (1995). +On-line+evaluation+of + meat. + CRC + Press.\&ots =yVajn6tn95\&sig=db2t1XI848evDwDHsDS8YZ7six 8\#v $=$ onepage $\& \mathrm{q}=$ Swatland $\% 2 \mathrm{C} \% 20 \mathrm{H} . \% 20 \mathrm{~J} . \% 20(1995) . \% 20$ On-line $\% 20$ evaluation $\% 20$ of $\% 20$ meat. $\% 20$ CRC $\% 20$ Press.\&f=false). 
Thomson, J. E., Lyon, C. E., Hamm, D., Dickens, J. A., Fletcher, D. L., \& Shackelford, A. D. (1986). Effects of electrical stunning and hot deboning on broiler breast meat quality. Poultry Science, 65(9), 1715-1719.

USDA - United States Department of Agriculture in poultry and products annual report 2018. Available in: (http:// www.usdabrazil.org.br/).

Van laak, R. L. J. M., Liu, C. H., Smith, M. O. \& Loveday, H. D. (2000). Characteristics of pale, soft, exudative broiler breast meat. Poultry Science, 79, 1057-1061.

Paper received: September $16^{\text {th }} 2020$.

Paper accepted: October $10^{\text {th }} 2020$.
Wilkins, L. J., Gregory, N. G., Wotton, S. B., \& Parkman, I. D. (1998). Effectiveness of electrical stunning applied using a variety of waveform-frequency combinations and consequences for carcass quality in broiler chickens. British Poultry Science, 39(4), 511-518.

WSPA - World Society for the Protection of Animals. (2010). Abate Humanitário de Aves, Rio de Janeiro, Brasil. 120p, (https://www.gov.br/agricultura/pt-br/assuntos/producao-animal/arquivos-publicacoes-bem-estar-animal/programa-steps-abate-humanitario-de-aves.pdf). 